\title{
PREGNANT WOMEN KNOWLEDGE ABOUT PRENATAL DEVELOPMENT: SUPPORT FOR HEALTH EDUCATION
}

\author{
Carolina Barretos Fernandes ${ }^{1}$, Fernando Silva Picon ${ }^{2}$, Ana Beatriz Paviotti ${ }^{3}$, \\ Thalita da Silva Canevarii ${ }^{4}$ Osni Lázaro Pinheiro ${ }^{5}$, Maria Angélica Spadella ${ }^{6}$
}

\begin{abstract}
Introduction: there is a series of studies related to intrauterine development, with significant advances in the elucidation of its molecular regulation and signalization, it is possible to notice that the perception by the pregnant woman about the development of the conceptus is not addressed in literature. The current studies on the pregnant woman perceptions about the conceptus are related to psychological aspects involving the fetus personification. A better understanding about the pregnant woman representations related to conceptus development can support the elaboration of educative actions, aiming at a qualified and humanized prenatal and puerperal care. Objective: to analyze the knowledge, worries and beliefs of a group of pregnant women regarding the prenatal development. Methods: a qualitative study was carried out, through semi structured individual interviews. The answers from the pregnant women were evaluated by the content analysis technique, under the thematic modality. Results: i t was observed that certain prenatal development processes are known by the pregnant women. This knowledge involves the following categories: physical characteristic and organic functions of the conceptus, the conceptus sex, establishment of the mother-conceptus bond, revelations of the ultrasound screening, concerns during the pregnancy and influence of superstitious beliefs in the pregnancy. Probably this knowledge has been transmitted by society, family, health team or through previous pregnancy experiences. However, this knowledge is misunderstood in its whole, presenting little correlation between the information accessed by the pregnant and, how much and how it was understood and assimilated. Conclusions: Therefore, interventions are needed, by means of health education.
\end{abstract}

Key words: embryonic and fetal development, pregnancy, health education, qualitative research.

\section{INTRODUCTION}

Gestation is a period marked by the surge of many expectations in relation to the birth of the future child that pervade the biological plane, triggered by the slow transformation of the cell in a new human being and also in the psychological plane, influenced by the preparation process of the mother for the relationship with this new being, by the construction of the so called imaginary baby ${ }^{1}$.

Several studies in the field of psychology verified the pregnant women conception about the process of fetus personification, some of them even refer to the maternal influence in the developing fetus, since this one demonstrates to prefer the mother's voice before other people's voices ${ }^{2,3}$.
Even before the advent of Embryology, the mysteries of intrauterine life have already raised large questions by the natural interest in knowing one's own origins. Historical records since the antiquity revel the search to uncover the inherent processes to the human prenatal development, investigation that keeps always advancing, evidenced in the scientific publications of modern embriology ${ }^{4,5}$.

However, literature in the biomedical area, shows that despite there are a series of studies about the intrauterine development, including significant advancements in the elucidation of its regulation and molecular signaling ${ }^{6}$, it can be seen that the perception that pregnant women have about the development of the conceptus is not addressed.

\footnotetext{
1 Resident Doctor of Psychiatry, Faculty of Medicine of Marília, Marília, São Paulo, CP 2003, CEP 17.519-030.

2 Resident Doctor of Medical Clinic, Faculty of Medicine of Marília, Marília, São Paulo, CP 2003, CEP 17.519-030.

3 Resident Doctor of General Surgery, Faculty of Medicine of Marília, Marília, São Paulo, CP 2003, CEP 17.519-030.

4 Resident Doctor of Medical Clinic, Faculty of Medicine of UNESP, campus Botucatu, Botucatu, São Paulo, CEP 18.600-000.

5 PhD Professor, Discipline of Pharmacology and from the Professional Masters Degree Program "Teaching in Health", Faculty of Medicine of Marília, Marília, São Paulo, CP 2003, CEP 17.519-030.

6 PhD Professor, Discipline of Human Embryology and from the Academic Masters Program "Health and Aging", Faculty of Medicine of Marília, Marília, São Paulo, CP 2003, CEP 17.519-030.

Work developed in the Department of Human Embryology, Faculty of Medicine of Marília, Marília, São Paulo.

Corresponding Author: maspadella@gmail.com
}

Suggested citation: Fernandes $\mathrm{CB}$, et al. Pregnant women knowledge about prenatal development: support for health education. Journal of Human Growth and Development 2013, 23(3): 282-289

Manuscript submitted Sep 16 2012, accepted for publication Jul 162013. 
A search performed in the MEDLINE/PubMed and Lilacs(Literatura Latino-Americana e do Caribe em Ciências da Saúde) and in SciELO (Scientific Electronic Library Online) databases, looking for recent papers covering pregnant women knowledge about prenatal development, did not returned results directly related with the theme.

However, the interest of pregnant women about the embryonic and fetal growth may be seen in studies that evidence the expectancies of mothers in relation to the ultrasonography. In this sense, Gudexet al. ${ }^{7}$, investigated the reasons why pregnant women opted by the ultrasonography to verify the conceptus development, even in the absence of clinical indication. The results show that among the most prevalent motives to perform the examination were the desire to follow-up the growing and intrauterine development of the conceptus and to verify anatomical abnormalities.

Therefore, the physical and functional development of the conceptus represents aspects that are normally linked to the maternal concern during the gestational period. The elucidation of the degree of knowledge that the pregnant woman has about the conceptus development, during the different phases of gestation might help the health teams in the implementation or fortification of works focused in health education.

Health education expects the involvement of community in programs that allow the occurrence of changes in the way of understanding the process of health and illness ${ }^{8}$. The obstetric and postpartum attention, precognizes the Ministry of Health', involves educational actions that allow the exchange of experiences between pregnant women and health professionals, since this exchange of information and experiences may facilitate to understand the gestational process.

The consecution of a initiative in health education focused in the pregnant expectations regarding the conceptus development must start from the prerogative of knowledge that the pregnant woman has about the development of the new being still in the uterine environment.

It is exactly in this aspect that lies the objective of this study, that is to analyze the knowledge, worries and beliefs of a group of pregnant women about prenatal development, providing a real diagnostic about their needs.

\section{METHODS}

This is a qualitative study of knowledge presented by pregnant women during prenatal development. This kind of study works with the universe of significances, motives, aspirations, beliefs, values and attitudes ${ }^{10}$.

For this purpose, pregnant women that were submitted to prenatal monitoring in three Family Health Unities (FHU) and that attended the course of pregnancy offered by a private health plan, during the first half of 2010, in the municipality of Marília, state of São Paulo, Brazil, were invited to take part in this study. Fifty-two pregnant women were effectively interviewed, being 43 from the FHU and nine from the course of pregnancy. Given that the conceptions about the theme may change according to the educational degree, socio-economic class and cultural level of the mother, the sample composition with pregnant women using both the public health service as well as a private ones was established due to the need to have a sample that would allow to investigate if those variables where related or not with the cognitions, concerns and beliefs about the intrauterine human growing.

As instrument for data collection was used the technique of semi-structured individual interview ${ }^{11}$, conducted by a guide of closed and open questions previously written, about socioeconomical and demographic data, gestational history, health data, besides questions about prenatal development. In order to validate it, a pilot study was performed with pregnant women that had similar characteristics to the target public, allowing the verification of its structures and clarity $^{12,13}$. After this procedure, it was needed to adequate the proposed roadmap by changing some questions so that they would generate an effective speech from the participants, replacing some misunderstood words and inverting the placement order of some questions during the interview.

In the beginning of each interview, the objective of the study was explained and, when agreed, each participant was asked to sign the Term of Free and Informed Consent. The interviews had an average length of 20 minutes, being mostly performed in the premises of the health unities and, in the case of some FHU users, data were collected at home. In order to ensure reliability and to preserve the original content, the interviews were recorded in digital voice recorders and transcribed by the responsible researcher.

For data analysis the option was to use content analysis, a thematic modality proposed by Bardin $^{14}$. Initially the reading of the interviews was made, aiming to organize the material and to recognize the initial ideas in the text. In the sequence, a deep study of the material was performed, oriented by the objective and theoretical reference, aiming at the identification of recording unities which made sense for the research. By clipping text, classification and aggregation of answers with common meaning and elements, a representation of the content was reached, aiming at the formulation of categories. After the categories were defined, relationships and deductions were established, subsidized by reflection and theoretical reference, allowing the production of considerations about the study ${ }^{10}$.

In the presentation of results, the testimonies of the pregnant women were codified with "Pbl" and "Prv", corresponding to public and private health service users, respectively, followed by a number 
equivalent to the sequence of interviews performed in order to preserve the anonymity of subjects.

This investigation was approved by the Committee of Research Ethics of the Medicine University of Marilia, under the study protocol number 213/09.

\section{RESULTS}

Profile of the interviewed pregnant women

Regarding the socio-demographic profile, most of the interviewees were in the age intervals between 20 and 24 years old (16 pregnant women) and between 25 and 29 years old (12 pregnant women). Regarding the marital status, most of the pregnant women declared to be married in stable union, in a total of 36 pregnant women. From the total of participants, 16 had completed high-school, 11 had incomplete fundamental school, 10 incomplete high-school, eight completed fundamental school and seven graduation. About social-economic data, 21 pregnant women coming from FHU declared to have a family income between one and two minimal wages. In the other extreme, four participants declared incomes of eight or more times the minimum wage, all of them participating in the group of private health insurance.

In the gestational history, half of the participants were primiparous and, among the multiparous ones, four declared to have four or more children. Most of the pregnant women were between the 20th and 37th weeks' of gestation, totaling 28 pregnant women, followed by 16 pregnant women between the 8th and 19th weeks, seven pregnant women with gestational age below eight weeks and one pregnant women who did not know it.

Thirty-nine interviewees said that current gestation was not planed. Most of them (43 pregnant women) declared that they never suffered or provoked an abortion and the remaining declared to have suffered one or more abortions.

\section{Knowledge, concerns and beliefs of pregnant women about prenatal development}

The investigation of pregnant women knowledge about the prenatal development was subsidized by the questions: How do you imagine your baby during the first gestational days? How do you imagine that your baby eats, urinates and form the feces? How do you imagine that your baby breathes being inside your belly? Do you thing that your baby's heart is like yours? Why? What do you think that defined the sex of the baby and when this happened? Do you talk to your baby? When did you start talking to him? From which moment did you realize that your baby was alive? What do you expect to see in ultrasonography? Do you have any fear during the gestation, explain? Do you have any superstition with respect to the development of the baby? Specify it.
The data analysis, taking as parameter the obtained speeches, allowed the definition of six thematic categories that express the knowledge, the concerns and beliefs about the prenatal development from the perspective of the interviewees: Physical characteristic and organic functions of the conceptus, Sex of the conceptus, Establishment of the mother-conceptus bond, Revelations of the ultrasound examination, Concerns during pregnancy and Influence of superstitious beliefs in the gestation.

\section{Physical characteristic and organic functions of the conceptus}

When questioned about how they imagined the conceptus during the first days of gestation, some pregnant women exposed the idea of human miniature, as can be verified in the reports:

"I imagine him small, hairy, black eyes". $\left(\mathrm{Pbl}_{10}\right)$

"Ah, he looks like my husband". ( $\mathrm{Pbl}_{2}$ ) Still in this conception, another pregnant woman expressed the concept of fetus personification, since the beginning of the gestation, mentioning: "I imagine it formed, normal". $\left(\mathrm{Pbl}_{3}\right)$

Despite the speeches reveling this knowledge as prevalent, some of the interviewees imagine the concept with spherical and minuscule morphology, named by them or by the family of "bean", "tiny bump", "pea", "little ball", "seed", and others, as in the speech:

"A minuscule grain. Then (...) we think that it looks like a bean because everybody says that it looks like a bean, a pea". ( $\left.\operatorname{Prv}_{3}\right)$

Similar to a seed that germinates and slowly takes the configuration of a plant, other mothers extend that same concept to what happens in the uterine environment, as in the report:

"A little grain, as it was a small plant growing inside of us". ( $\left.\mathrm{Pbl}_{5}\right)$

On the other hand, some pregnant women demonstrated a more technical knowledge, mentioning the concept of single cell, possibly referring to what is scientifically called zygote or egg cell, as found in the reports:

"A cell that is taking the shape of a human being, as it can be seen by ultrasound". $\left(\operatorname{Prv}_{2}\right)$ "To tell the truth, during the first days it is not ... it is more like a shapeless ... a big cell". $\left(\mathrm{Pbl}_{33}\right)$

As for the organic functions executed by the fetus, most of the interviewees believed that it gets its nutrition in the uterus by the umbilical cord, structure whose name is widespread among the mothers. However its functioning, normally, is misunderstood, being confused with the umbilicus. The following reports make it explicit: 
"[...] because I think that when I eat he moves more, he flounders inside me and this is through the navel". ( $\mathrm{Pbl}_{6}$ ) "[...] some say that it is by the umbilical cord that we eat and it keeps pulling". $\left(\mathrm{Pbl}_{8}\right)$

Most of the participants were unaware about the fetal urination function and those who had the information, could not conceive how this function could happen in the intrauterine life, as exposed in the speech:

"Yes ... when I went to the Women Hospital they told me that his bladder was full, but I don't know how". ( $\left.\mathrm{Pbl}_{8}\right)$

Other speeches report an idea closer to the physiological mechanism of fetal swallowing of amniotic fluid, mentioning:

"He swallows the liquid and process it like us and then excretes". ( $\left.\operatorname{Prv}_{2}\right)$

"Even in the ultrasound we can see that he is opening the mouth, then we think that he is taking the liquid". ( $\left.\operatorname{Prv}_{6}\right)$

"For now I don't think that he urinates. But I know that by the end of the gestation he does. Because it is at the end of the gestation that he learns how to nurse ... because during my first gestation I had much liquid in my bag, as if she was swallowing ... because she pees and then swallows it again". $\left(\mathrm{Pbl}_{33}\right)$

Generally speaking, there was surprise from the pregnant women questioned about the formation of feces and fetal evacuation, unaware about how this process happens. A pregnant woman mentioned the possibility of those events based in the experience of her previous pregnancy, intuitively referring to the meconium:

"I believe because my other daughter was a bit late and "pooped" inside my belly". ( $\left.\mathrm{Pbl}_{4}\right)$

On fetal breathing and how it could happen with the fetus inside the amniotic sac, most of the pregnant women believed that the fetus could breath, but were unaware of its feasibility. From the pregnant women who reported how this organic function could happen, most of them mentioned that the breathing would happen through the umbilical cord. However, some pregnant women considered that the fetal breathing is similar to their own, conceiving the idea of pulmonary respiration existence:

"I think that on the same way that I breath, I think that ... kind off ... there is a float, I don't know ... someway that he is breathing ... alive you know...". ( $\mathrm{Pbl}_{6}$ )

Another pregnant woman reported the possibility of gill breathing in the fetus, which is found in lower vertebrates, reporting: "I imagine that it should be like in the animals that live in the water". $\left(\operatorname{Prv}_{1}\right)$
Some pregnant women composed the idea that what really happens for the fetus is the ventilation, addressing the effective physiological mechanism. The following report is an example:

"I know that he has little lungs formed, but I think that it is too soon. I think that my oxygen from breathing leaves the blood and goes to him". $\left(\mathrm{Pbl}_{34}\right)$

In relation to the morphology of the fetus heart, a large parcel of the pregnant women answered that the fetal heart is small, when compared to the adult one:

"No, it is different, tiny". ( $\left.\mathrm{Pbl}_{1}\right)$

"It is still being formed, in a growing phase". $\left(\mathrm{Pbl}_{40}\right)$

"I think that it is still small... because it is still in formation, growing". $\left(\mathrm{Pbl}_{34}\right)$

Considering that most of the pregnant women had heard the fetal heartbeats at least once during the prenatal consultations, the reports indicating that the fetal heart rate is higher than their own were prevalent:

"I was commenting that his heart is beating very fast". $\left(\mathrm{Pbl}_{24}\right)$

"I don't think it is the same [...] seems like a small horse racing". $\left(\mathrm{Pbl}_{15}\right)$

\section{Sex of the conceptus}

Most of the participants were unaware of the process of sex determination of the fetus. However, some of them recognized that it is an episode that happens at fertilization, or at least, in the beginning of gestation, as the speeches show:

"And this happens right in the very beginning". $\left(\mathrm{Pbl}_{21}\right)$, "I believe that it happens during fertilization". ( $\left.\mathrm{Pbl}_{40}\right)$, "Before, right? During the relation". $\left(\operatorname{Prv}_{1}\right)$.

Some pregnant women reported that the determination of fetal sex depends on the man, although unaware of how it could happen:

"The only thing that I know and that I heard in school, is that who determines the sex is the man [...] but how and why I don't know". $\left(\operatorname{Prv}_{3}\right)$

"The father is the guilty one!". ( $\left.\operatorname{Prv}_{6}\right)$

"[...] who defines the sex is the husband, I know it's him because he wanted to have a girl and a boy came and I said that it was his fault." $\left(\mathrm{Pbl}_{27}\right)$

In contrast, one pregnant woman reported that the definition of fetal sex depends both on maternal genes as well as in paternal ones:

"Genes, both the ones from my husband and mine, in the moment of fertilization". $\left(\mathrm{Pbl}_{18}\right)$

Two pregnant women advanced in the explanation of the process, mentioning the different relationship among paternal and maternal sexual chromosomes: 
"[...] who determines the sex is the sperm, because the man has $X$ and $Y$, at least in my mind and it depends in the act of conception if it is $X$ is a girl and if it is $Y$ is a man". ( $\left.\operatorname{Prv}_{8}\right)$ "[...] I remember that women are " $X$ " only. And men have the " $X$ " and the " $Y$ ". And then depends ... there are several theories ... that I can't explain ... But who gives the sex to the baby is the man". $\left(\mathrm{Pbl}_{33}\right)$

With a parallel reasoning, some speeches reported the genetic component of individuals as the factor responsible by the sexual definition, as observed in the comments:

"Determined by the gene". $\left(\operatorname{Prv}_{1}\right)$, "I have no idea, genetics?". ( $\mathrm{Pbl}_{16}$ )

Besides, the sexual definition as being an event previously determined by God or by destiny composed some of the answers found:

"I think it is God who chooses". (Pbl $\left.{ }_{10}\right)$, "It's destiny, isn't it? It is what it is!". $\left(\mathrm{Pbl}_{37}\right)$

\section{Establishment of the mother-conceptus bond}

Most of the mothers were talking with the conceptus since they discovered or accepted the pregnancy, a fact that demonstrates the beginning of the emotional link establishment, not being relevant, in this moment, the development or not of the sensorial organs of the fetus and its capacity to react of not to the external stimuli, since for the mother the important is the creation of this loving and welcoming tie. The reports exemplify:

"Oh... after about two weeks, as soon as I discovered to be pregnant". ( $\left.\mathrm{Pbl}_{5}\right)$

"I talk a lot... every time that I was anxious I told her to not care about it, when I was in the car ... Oh! Since the beginning when I discovered that I was pregnant. ( $\operatorname{Prv}_{7}$ )

"I started to talk around the third month, three and a half months when I started to accept and even apologized for not having accepted it before" $\left(\mathrm{Pbl}_{34}\right)$

A small parcel of pregnant women established a relation between the beginning of the talk with the conceptus and the fetal kinetic, as highlighted by the speech:

"I talk since the fourth month ... when he started to move...". (Pbl $\left.{ }_{15}\right)$

Regarding the time when the pregnant had the perception that the conceptus was alive, most of the pregnant women related this vitality to the bodily sensation of the first fetal movements:

"From the moment when he moved. It was after 24 weeks". $\left(\mathrm{Pbl}_{28}\right)$

Besides this factor, other pregnant women reported that the evidence of fetal vitality happened during the first ultrasound examination due to listening the fetal heartbeats, as can be observed in the speech:

"From the moment when I listened his small heart beating". $\left(\mathrm{Pbl}_{5}\right)$

Others justified this perception of fetal vitality with the changes that pregnancy brought in her bodies, such as the belly growing, the sickness and the menstrual delay:

"But we feel, because I feel ... Because sometimes I get out of bed quickly, and I feel a bit of dizziness ... I feel my belly growing" $\left(\mathrm{Pbl}_{19}\right)$.

Still in this subject, some women reported that they knew that the conceptus was alive since they discovered to be pregnant, demonstrating an affective and intuitive feeling, sometimes, bereft of reason, as in the report:

"Since the moment when I discovered that I ... that he was inside me. Do you understand? Since the first week, the first month that he was there" $\left(\mathrm{Pbl}_{32}\right)$.

\section{Revelations of the ultrasound examination}

As for what the pregnant women expected to see in the ultrasonography, most of them associated to the possibility of the couple to discover the sex of the conceptus:

"Oh, I wished to have a girl, but now I don't know ... now what will come will be fine, to avoid being disappointed". $\left(\mathrm{Pbl}_{23}\right)$

For other pregnant women, the ultrasound represents a mean of following-up the morphogenesis and health of the conceptus, as well as for detection of congenital anomalies and fetal distress, as evidenced in the speeches:

"That everything is ok with the members, when it is a bit bigger we can do the morphologic and see the organs". ( $\left.\operatorname{Prv}_{2}\right)$

"[...] to know what is happening, when the little hand is being formed, the nail, hairs, everything" ( $\left.\operatorname{Prv}_{6}\right)$.

"I want him to be perfect...". ( $\left.\mathrm{Pbl}_{25}\right)$

"His health state, [...] because we don't want that he will born with a malformation, with hydrocephalus". $\left(\mathrm{Pbl}_{31}\right)$

\section{Concerns during pregnancy}

Among the reported concerns, the pregnant women which exposed their fears, related them with the inability to carry the pregnancy until the end, pointing questions such as bleedings, abortions, complications in childbirth, prematurity and congenital malformations:

"I am afraid to lose it. I had a dilation and a start of bleeding". ( $\left.\operatorname{Prv}_{2}\right)$

"Yes... to be born deformed, to be born without some finger in the foot, those things". $\left(\mathrm{Pbl}_{25}\right)$ 
"To be born before time, stay in ICU, those things ... if the little heart stops beating we die of fear". $\left(\mathrm{Prv}_{7}\right)$

It also became evident for some pregnant women the worry with abnormalities in positioning and structure of the umbilical cord, probably afraid that it will tangle around the baby and/or suffer prolapses:

"Normally I ask to see the cord, how the cord is". $\left(\operatorname{Prv}_{3}\right)$

Despite the pregnant participants reporting concerns during gestation, it is perceived in their speech that this feeling is eased by the trust that the mother puts in a divine power protecting the conceptus.

\section{Influence of superstitious beliefs in the gestation}

Most of the pregnant women mentioned that they have no superstition about women in pregnancy. Despite that, in some speeches the idea that some dietary will not satiated during pregnancy could cause the baby to born with some mark or affection reminding the food in question was detected:

"If I don't eat something that I want, he may be born with the face of that". ( $\left.\operatorname{Prv}_{1}\right)$

"[...] during my first pregnancy, I had a strong wish to eat crab cone, then I did not eat it and my daughter has a small mark that looks like a cone". $\left(\mathrm{Pbl}_{34}\right)$

Some other peculiar reports of superstitions comprised the following situations: possibility of the umbilical cord to tangle in the fetus neck if the mother passed under a fence, appearance of congenital malformations as a result of incestuous relationship between father and daughter, preterm delivery after a scare, some mark in the mother during gestation leads the child to born with the same mark and the use of tight clothes may cause malformation in the conceptus.

\section{DISCUSSION}

In the analysis of pregnant women view about prenatal development, it is noted that, normally, there is ignorance about some processes that permeate this period of human development. On the other hand, this unawareness is not configured by the total absence of information, because most of the representations reported by women is greatly subsidized by cultural and/or social questions, rooted in their imaginary, that are spread in society and pass from generation to generation over the years. In view of this, the prevalent means of obtaining information by pregnant women come from family reports, from experiences in previous gestations, from prenatal consultations, from reading specialized materials, from courses for pregnant women and finally, from beliefs.

Even if the pregnant women know some process of conceptus formation, it is observed that this is a misunderstood knowledge in its fullness, demonstrating little correlation between the information that the pregnant woman had access to and how much and how she understood and actually has appropriated. For example, it can be cited the umbilical cord that, despite future mothers bringing with them the crucial importance of that structure for the conceptus, because they relate it with the its survival, they have many questions and curiosities regarding its functioning.

The knowledge about how the conceptus would be physically during its first days of development, evinces that for some mothers the conceptus is a miniature man, with a developed but small body. This conception of previously formed body is present since the Renaissance ${ }^{4}$ and reflects the personification that the mother does about the fetus, that is important so she does not encounters an unknown individual at delivery time ${ }^{15,16}$. Besides, Aulagnier ${ }^{15}$ complements that the image that the future mother has of the child body being generated, allows her to dimension him as belonging to the human race, of which she is part, being, therefore, ruled by the same laws.

The concept that prenatal development comes from a single cell extremely specialized until the final formation of a fetus, is related to reports of other pregnant women that refer to the conceptus as a "small bean", "small ball" or "seed", giving the notion of something very small, without a defined human shape, that will develop, grow and generate a complex organism, despite being unaware of how this transformation will happen during gestation.

Addressing the physiological mechanisms of the fetus in intrauterine life such as nutrition, breathing and excretion, it is observed from the reports that, most of the pregnant women show closer approximation with organic functions of nutrition and breathing, since they attribute the participation of the umbilical cord in both of them. Despite the unawareness about how those processes happen, even with reports of the existence of pulmonary respiration in fetuses, it appears that in pregnant women view, the umbilical cord plays a vital role in the conceptus development.

The cardiac development represented the event over which the pregnant women had more knowledge due to their experiences of listening the cardio fetal heartbeats during the medical consultations, besides their visualization in ultrasound. In Larsenet's al. ${ }^{17}$ study it is verified that from 493 answers of pregnant women about their expectancies in the ultrasound examination, 47\% wished to see the fetal heart beatings. Thus, it is perceived that the knowledge about the development and functionality of that specific organ is closer to the pregnant women, being evidenced month after month in the prenatal follow-up. 
With respect to the sex determination of the conceptus, it is evidenced that the pregnant women related it to the male gamete and to the beginning of pregnancy, but also attribute this determination to both parents or to some divine desire. Stronger yet, when addressing this subject it is perceived that the pregnant women are moved by the expectancy of knowing the fetus sex and not how it is determined. Data in literature reinforce this as an important aspect for couples and family members, particularly for the mother, that normally refers to a positive reaction at the moment when she receives the information of the fetal sex, regardless of whether it matched or not her preference $^{3,16}$.

The dialog with the conceptus, along the gestational period is something present in the daily life of the pregnant, representing one way to establish an effective maternal bond with that being in full development. This communication motherconceptus independently of the gestational age is in line with several studies, which addressed the relationship mother and fetus in the beginning of the intrauterine life, will be the foundation of the mother-son bond after birth and along the whole development of the child ${ }^{16,18}$. The imaginary bond with the son before birth, thinking about him and imagining his characteristics, allows the construction of this individual representation ${ }^{19}$. Besides, the association between the beginning of the talk mother-conceptus and the fetal moving by events of concrete nature such as kicks and/or the change of the maternal body due to the belly growing, establish a process that starts the so called primary attachment, in which a personality is attached to the child by means of the perceptions of mothers regarding the fetal movements, which may even impersonate those movements, feeling the fetus as more real 2,3 .

The expectancies of pregnant women regarding the ultrasound examination refer to the possibility of discovering the fetal sex, being evident that this is an important factor for the couple and family members in the generation of hopes and feelings regarding the developing child. It can be seen that the ultrasound represents a mean of detecting problems during the gestation, that is associated with the mother concerns about the development and health of the conceptus. Those concerns evidenced in the reports are corroborated in literature, which shows that the maternal expectation during the ultrasonographic evaluation relates enormously to parameters that allow to ascertain the health and fetal wellbeing, permeating also the exclusion of congenital abnormalities ${ }^{7,17}$. In this sense, the pregnant women see the ultrasonography as a way to calm down about the development of the child that they are waiting, which may be found in the study of Ekelin et al. ${ }^{20}$ that shows that the state of concern of the pregnant women has a significant reduction after this examination is performed.

The pregnant women manifestations with respect to the influence of beliefs along the gestation show an intimate relationship with the meanings and representations that emerge from the socialcultural context of those women, being related to the maternal imaginary, and incorporated to the thinking of the couple and family members ${ }^{21}$. The parental and familiar involvement in the representations of the pregnant women is important since the gestation, because it may contribute for the establishment of an effective social support to the women having an impact on the future experience of maternity and child development ${ }^{21}$.

The data analysis allows to discover that despite the group of participating pregnant women being heterogeneous with respect to social, economic or educational aspects, it is evident that both pregnant women users of public health services as well as private users, at the same time that they know some aspects of the human prenatal development, they manifest with minimal distinction beliefs that are far away from the current scientific precepts.

Besides the correspondence of the acquired knowledge, it is observed that Maldonado's assertion that a group of pregnant women becomes homogeneous is applied to this research, considering that they are women going through a common existential transition, having similar problems and willing to discuss situations common to all. In that way, the knowledge, concerns or superstitions presented by the interviewees as they live through their gestations, puts them in a shared situation of intense vulnerability.

The more information is possessed about the pregnant women for whom is wished to promote educational actions in consonance with the public policies of integral care to woman health, the better and more effective will be the prenatal care to be provided $^{23,24}$. Thus, it is expected that with the presented data it will be possible to give a greater visibility to pregnant women needs, from their own perspective, providing an important subsidy to best intervene with respect to mother and fetus wellbeing during the prenatal follow-up, by means of educational actions in health.

Finally, having the dimension of the real knowledge of pregnant women, from their reality, values, beliefs and uses, it is possible to capacitate health professionals working directly with this public to develop actions in health, beginning by education, understanding them as subjects, more fully, ensuring a prenatal assistance of quality and humanized.

\section{Acknowledgements}

To the Foundation of Support to Research in the State of São Paulo - FAPESP by the financial support provided to this research. 


\section{REFERENCES}

1. Ferrari AG, Piccinini CA, Lopes RS. O bebê imaginado na gestação: aspectos teóricos e empíricos. Psicol Estud. 2007,12(2):305-13.

2. Azevedo EC, Moreira MC. Psiquismo fetal: um olhar psicanalítico. Diaphora. 2012,12(2):64-9.

3. Piccinini CA, Gomes AG, Moreira LE, Lopes RS. Expectativas e Sentimentos da Gestante em Relação ao seu Bebê. Psic: Teor e Pesq. 2004,20(3):223-32.

4. Needham J. A history of embryology [Internet].CUP Archive, 1959. Chapter II, Embryology from the Galen to the Renaissance, p. 57-95 [cited 2013 Apr 10]. Available from: http://books.google.com.br/books?hl=pt$B R \& \mid r=\& i d=F s g 5 A A A A I A A J \& o i=f n d \& p g=P$ $\mathrm{R} 1 \& \mathrm{dq}=$ the + history + of + embryology \&ots $=6$ _CiMRyWfn\&sig=TQDV_EIbOxoXr1p6Q0q P BTs G jw q $\#$ v = o n e page \& q = the $\% 20$ history\%20of\%20embryology\&f=false

5. Murillo-González J. Evolution of embryology: A synthesis of classical, experimental, and molecular perspectives. ClinAnat [Internet]. $2001 \mathrm{Apr}$ [cited $2013 \mathrm{Apr} 10], 14: 158-63$. Available from: http://onlinelibrary. wiley.com/ doi/10.1002/10982353(200103)14:2\% 3C158: :AID-CA1025\%3E3.0.CO,2-Q/pdf

6. Zhu Z, Huangfu D. Human pluripotent stem cells: an emerging model in developmental biology. Development. 2013,140(4):705-17.

7. Gudex C, Nielsen BL, Madsen M. Why women want prenatal ultrasound in normal pregnancy. Ultrasound Obstet Gynecol. 2006,27:145-50.

8. Vila ACD, Vila VSC. Trends of knowledge production in health education in Brazil Rev Latino-am Enfermagem [Internet]. $2007 \mathrm{Apr}$ [cited 2013 Apr 6],15(6):1177-83. Available from:http://www.scielo.br/pdf/rlae/v15n6/ 18.pdf

9. Brasil. Pré-Natal e Puerpério: Atenção qualificada e humanizada. Manual técnico/ Ministério da saúde. Secretaria de atenção à saúde. Departamento de ações programáticas e estratégicas. Brasília: Editora do Ministério da Saúde, 2006.

10. Minayo MCS, Deslandes SF, Neto OC, Gomes R. Pesquisa social: teoria, método e criatividade. $21^{\text {a }}$ ed. Rio de Janeiro: Vozes, 2007.

11. Manzini EJ. Considerações sobre a elaboração de roteiro para entrevista semiestruturada. In: Marquezine MC, Almeida A, Omote S, editores. Colóquios sobre pesquisa em educação especial. Londrina: Eduel, 2003. p. 11-25.
12. Richardson RJ. Pesquisa social: métodos e técnicas. $3^{a}$ ed. São Paulo: Atlas, 1999. Capítulo 12, Questionário, p. 189-206.

13. Rea LM, Parker RA. Desenvolvendo perguntas para pesquisas. In: Rea LM, Parker RA, editores. Metodologia de pesquisa: do planejamento à execução. $1^{a}$ ed. São Paulo: Pioneira, 2000. p. 57-75.

14. Bardin L. Análise de conteúdo. Lisboa: Edições 70, 1995.

15. Aulagnier $P$. Nacimiento de uncuerpo, origen de una historia. In: Hornstein L, editor. Cuerpo, historia, interpretación. Buenos Aires: Paidós, 1994. p. 117-70.

16. Piccinini CA, Ferrari AG, Levandowski, DC. O bebê imaginário e as expectativas quanto ao futuro do filho em gestantes adolescentes e adultas. Interações. 2003,16:81-108.

17. Larsen T, Nguyen, TH, Munk M, Svendsen L, Teisner L. Ultrasound screening in the $2^{\text {nd }}$ trimester. The pregnant woman's background knowledge, expectations, experiences and acceptances. Ultrasound Obstet Gynecol. 2000, 15:383-86.

18. Alhusen JL. A literature update on maternalfetal attachment.JOGNN. 2008,37: 315-28.

19. Borsa JC. Considerações acerca da relação mãebebê da gestação ao puerpério. Contemporânea - Psicanálise e Transdisciplinaridade [Internet]. 2007 Apr [cited 2013 Apr6],2:310-21. Available from: www.contemporaneo.org.br/contemporanea.php

20. Ekelin M, CrangSvalenius E, Larsson AK, Nyberg P, Mars 'al K, Dykes AK. Parental expectations, experiences and reactions, sense of coherence and grade of anxiety related to routine ultrasound examination with normal findings during pregnancy. Prenat Diagn 2009, 29: 952-59.

21. Rapoport A, Piccinini CA. Apoio social e experiência da maternidade. Rev Bras Crescimento Desenvolv Hum. 2006, 16(1): 85-96.

22. Maldonado MT. Psicologia da gravidez: parto e puerpério. $4^{a}$ ed. Petrópolis: Vozes, 1981. Capítulo 1, Aspectos psicológicos da gravidez, do parto e do puerpério, p. 11-65.

23. Souto KMB. A política de atenção integral à saúde da mulher: uma análise de integralidade e gênero. Ser social. 2008,10(22):161-82.

24. Moura ERF, Rodrigues MSP. Comunicação e informação em saúde no pré-natal. Interface Comun Saúde Educ. 2003,13:109-18. 